\title{
JAKARTA ISLAMIC INDEX: COVID-19 PANDEMIC AND POTENTIAL FINANCIAL DISTRESS
}

\author{
Avianto Nugroho ${ }^{a}$ \\ Wasiaturrahmab \\ Putri Anggiac \\ aslamic Economics Department, Faculty of Islamic Economics and Business, State Islamic \\ University of Sunan Kalijaga Yogyakarta \\ ${ }^{b}$ Department of Economics, Faculty of Economics and Business, University of Airlangga \\ 'Department of Law, Universitay of Muhammadiyah Yogyakarta \\ Email: avianto.hr@gmail.com ${ }^{\text {a }}$ rahma@feb.unair.ac.id ${ }^{\mathrm{b}}$; putrianggia@umy.ac.id ${ }^{\mathrm{c}}$
}

\section{ARTICLE HISTORY \\ Received: \\ 30 March 2021 \\ Revised \\ 01 October 2021 \\ Accepted: \\ 26 November 2021 \\ Online available: \\ 30 November 2021 \\ Keywords: \\ COVID-19, \\ Financial Distress, \\ Liability, \\ Liquidity, \\ Profitability, \\ Zwesky Model.}

*Correspondence:

Name:

Avianto Nugroho

Email:

\section{ABSTRACT}

This research aims to analyze the potential for financial distress of Islamic companies that are included in the Jakarta Islamic Index during pandemic of COVID-19, which is using profitability ratios, liability ratios, and liquidity ratios (Zwesky's Model). The sample is quarterly (2019 to 2020) and it is using the Generalized Method of Moments (GMM) panel data model approach that was developed by Arellano and Bond (1991). The results of this study indicate that the profitability ratio has the most influence on corporate financial distress and from the overall this research occurs in the process of decreasing company financial performance during pandemic of COVID-19. Moreover, there is one company that indicates financial distressed, there are twenty-two companies that experienced a decline in financial performance, but there are 7 companies that experiences better financial performance when the COVID-19 pandemic occurred. In one hand, this shows that COVID-19 has a broad effect on the decline in the financial performance of sharia companies. On the other hand, it has a positive impact on certain companies that works specifically in sectors which is related to information technology.

\section{INTRODUCTION}

Starting the year 2020 in the international world was shocked by the COVID19 pandemic, or better known as the Corona Virus, the acute disease of severe acute respiratory syndrome (SARS-CoV-2/Coronavirus 2). COVID-19 itself was first identified in the Chinese city of Wuhan, around December 2019 (Arnani, 2020). This pandemic then spread throughout the world and has an economic impact that can be felt by most of the world's economic actors. Some countries have announced that this pandemic has caused recession in several countries during certain periods, including 
Indonesia through the Central Bureau of Statistics and the Ministry of Finance on November 5, 2020, which announced negative economic growth for three consecutive quarters.

The International Monetary Fund (IMF) predicts that global economic growth will decline by $3 \%$ in 2020 , economic growth in developed countries will decline by $6.1 \%$, developing countries will decline by $1 \%$. World trade is estimated in between $13 \%$ and $32 \%$ by 2020 as the COVID-19 pandemic disrupts normal economic activities and lives around the world (WTO, 2020). The global inflation rate is estimated at $3 \%$ in 2020 , the inflation rate in developed countries is around $0.5 \%$, while in developing markets and developing countries it is $4.6 \%$ (World Economic Outlook, 2020). The United Nations Conference on Trade and Development predicted that the flow of foreign capital/global investment (foreign direct investment) will fall sharply to $40 \%$ during 2020-2021, reaching its lowest level (UNCTAD, 2021).

The COVID-19 pandemic forces the government to issue Government Regulation number 21 of 2020 concerning Large-Scale Social Restrictions (PSBB) in the context of the Acceleration of Handling Corona Virus Disease 2019, which is followed by implementing regulations for the Regulation of the Minister of Health of the Republic of Indonesia Number 9 of 2020 concerning Guidelines for Large-Scale Social Restrictions. With the existence of this legal of medical health, some provinces and cities/districts carry out the implementation of the PSBB, including school and work vacations, restrictions on religious activities, restrictions on activities in public places or facilities, limitation of social and cultural activities, restrictions on transportation modes, restrictions on other activities specifically related to defense and security aspects, (Listyorini, 2020).

By the COVID-19 pandemic and the large-scale social restriction (PSBB) policy, it has a direct impact on the economy. This can be seen from the economic growth report issued by the Central Bureau of Statistics (BPS) in the third quarter of 2020 as shown in the following figure:

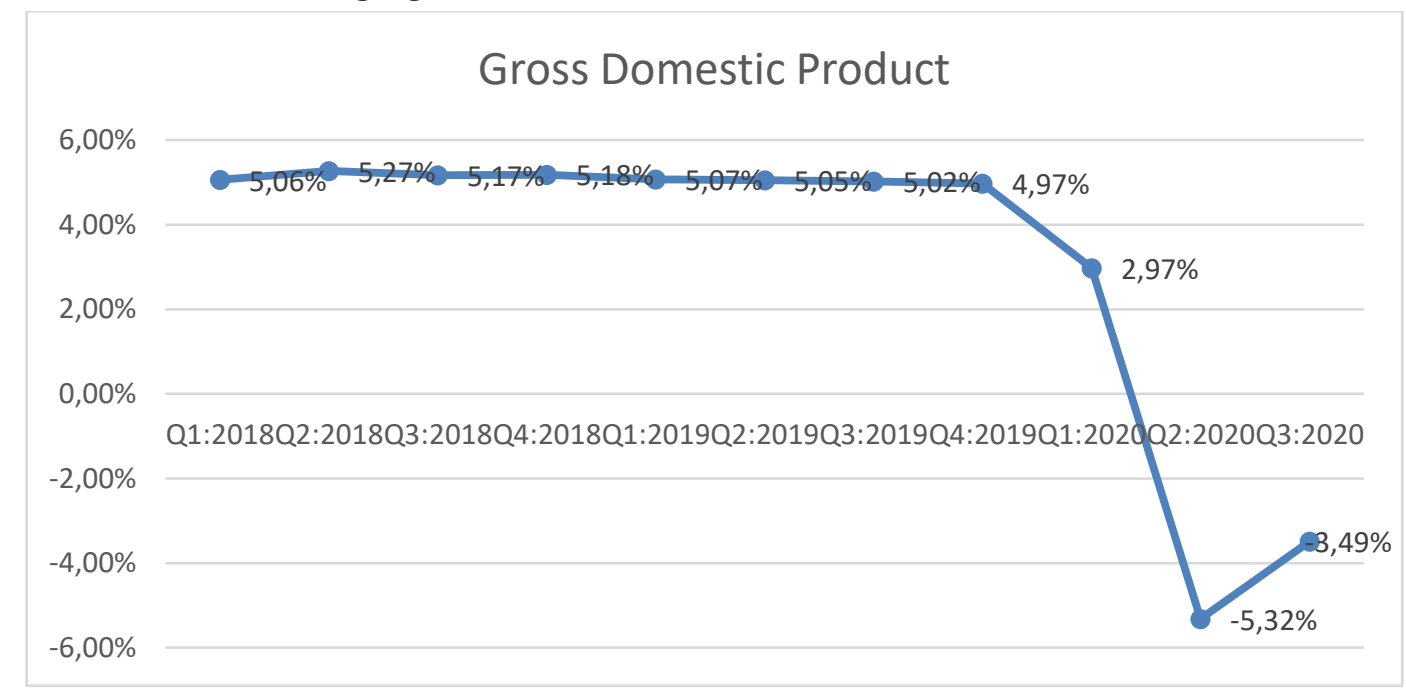

Figure 1. GDP (Gross Domestic Product) Indonesia (Q1 2018 - Q3 2020)

Source: Central Bureau of Statistics (2020) 
The graph above shows economic growth starting from 2018 first quarter to 2020 third quarter economic growth, where in there are signs of a decline in economic growth for the fourth quarter of 2019 to the first quarter of 2020, followed by a sharp decline in GDP in the first quarter period 2020 to the second quarter of 2020.

The impact of the COVID-19 pandemic is inevitable in various business sectors, including the capital market, which can be seen from the decline in share prices and the decline in share trading volume as shown in the following chart:

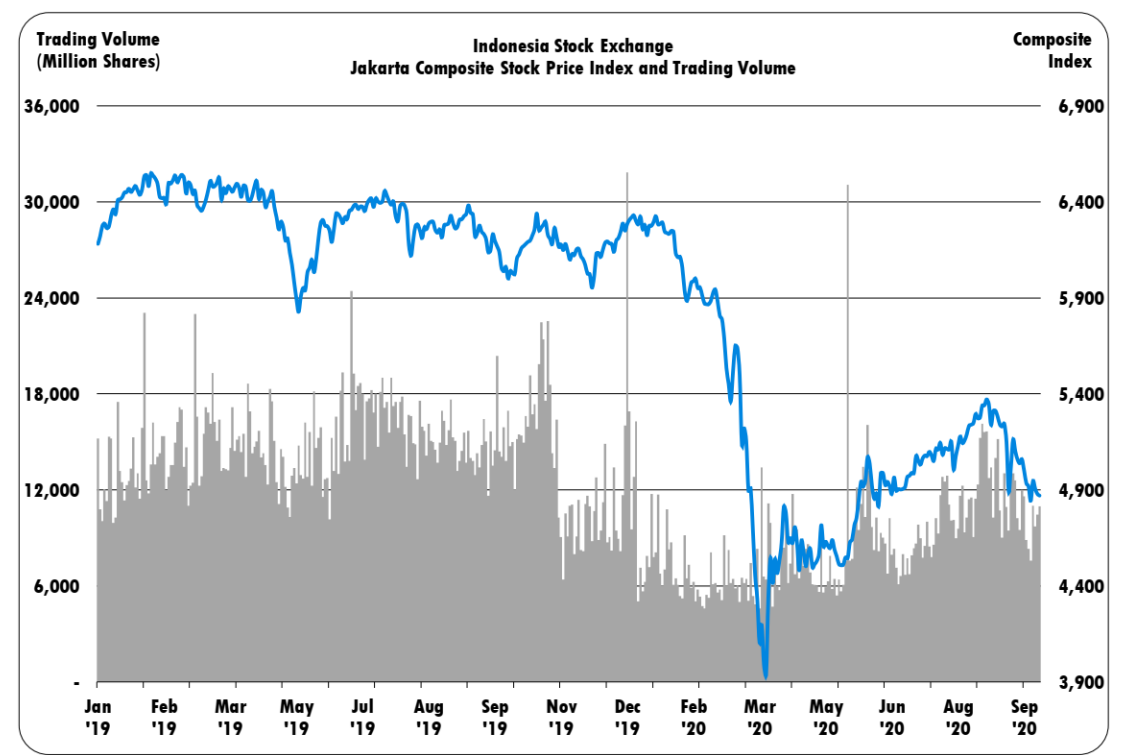

Figure 2. Jakarta Composite Stock Price Index and Trading Volume Source: IDX Quarterly Statistics, $3^{\text {rd }}$ Quarter 2020

The graph shows that the decline occurred from early 2020, followed by a sharp decline in the same price and volume in March 2020. The Indonesia Stock Exchange (IDX) experienced a sharp decline in trading volume, which is the average daily trade turnover was around IDR7,724 billion.

Indonesia as a country of a majority Muslim population, which can also be described as part of the investors and capital market players in the IDX, then the following is a graph of the Islamic capital market which the Jakarta Islamic Index (JII) may represent: 


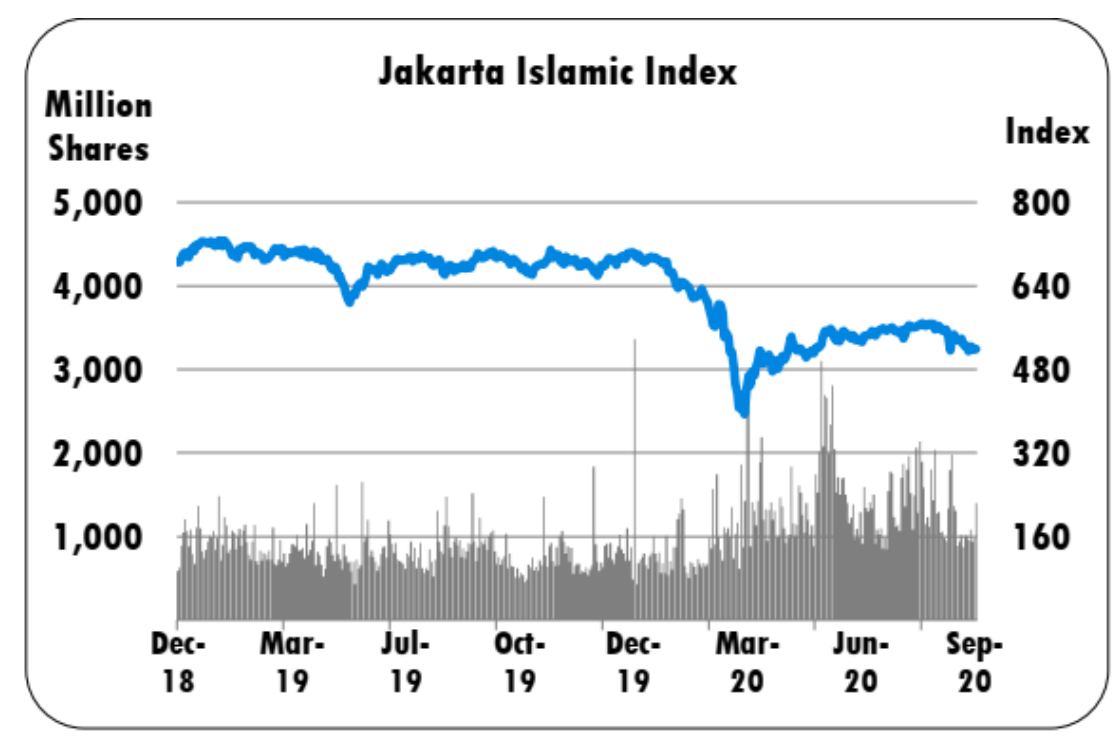

Figure 3. Jakarta Islamic Index Stock Price Index and Trading Volume Source: IDX Quarterly Statistics, $3^{\text {rd }}$ Quarter 2020

The economic crisis caused by the COVID-19 pandemic on the world of capital markets. Moreover, it gives some affects the Islamic capital market generally, in this case represented by the $\mathrm{JII}$, which is part of the national capital market. This is caused by the Islamic capital market that cannot be separated from the national economy. Furthermore, the Islamic capital market interacts with the outside world, namely with stakeholders who support its daily operations, its parent company and its investors. So that the Islamic capital market (Jakarta Islamic Index) is not spared from the impact of the crisis caused by the COVID-19 pandemic.

This study is based on a report of Fernandes (2020). He stated that the onset of the COVID-19 pandemic which were forced the majority countries to implement tightening measures, also known as lockdown or semi-lockdown. It means a regional lockdown policy for an indefinite period. This policy was forced to face travel bans, bans on gatherings, stopping or reducing some transportation, and banning of certain foods. Thus, it declined the activity. The data shows that global industrial output fell by more than 13.5 percent in the first two months of 2020. Moreover, investment in fixed assets fell by $25 \%$ year-on-year, while infrastructure investment fell by $30 \%$ year-on-year. The facts on the capital market (stocks) can be found by looking at the world's major stock indexes, such as the Dow Jones Industrial Average. It is set a new low with a drop of 2,977 points in a single day on March 16, 2020, and several wellknown companies whose share prices have fallen by 80 percent in recent years. The following visual depicts the global drop in many stock indexes: 
Avianto Nugroho, Wasiaturrahma, Putri Anggia

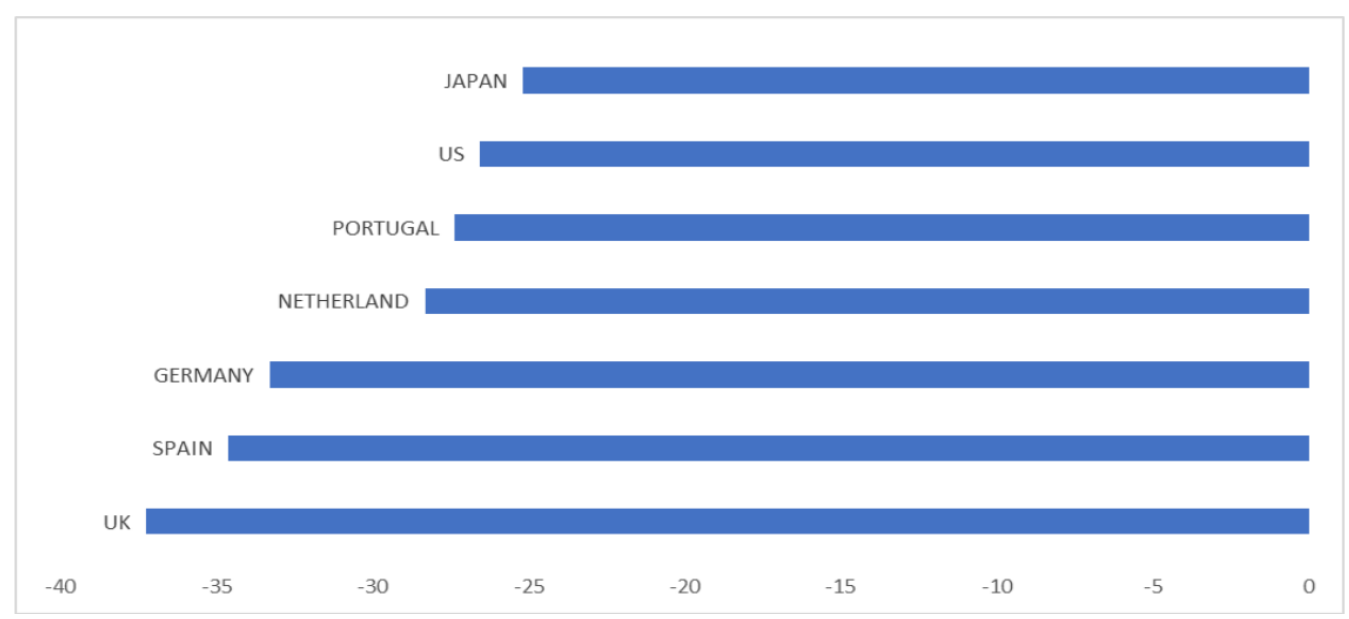

Figure 4. Global Capital Market Performance in 2020

Source: Fernandes (2020)

The graph shows that the world's largest global financial markets have fallen (negative) by an average of $30 \%$. The following images show the world's major capital markets as the 11th poorest performing global capital markets in 2020:

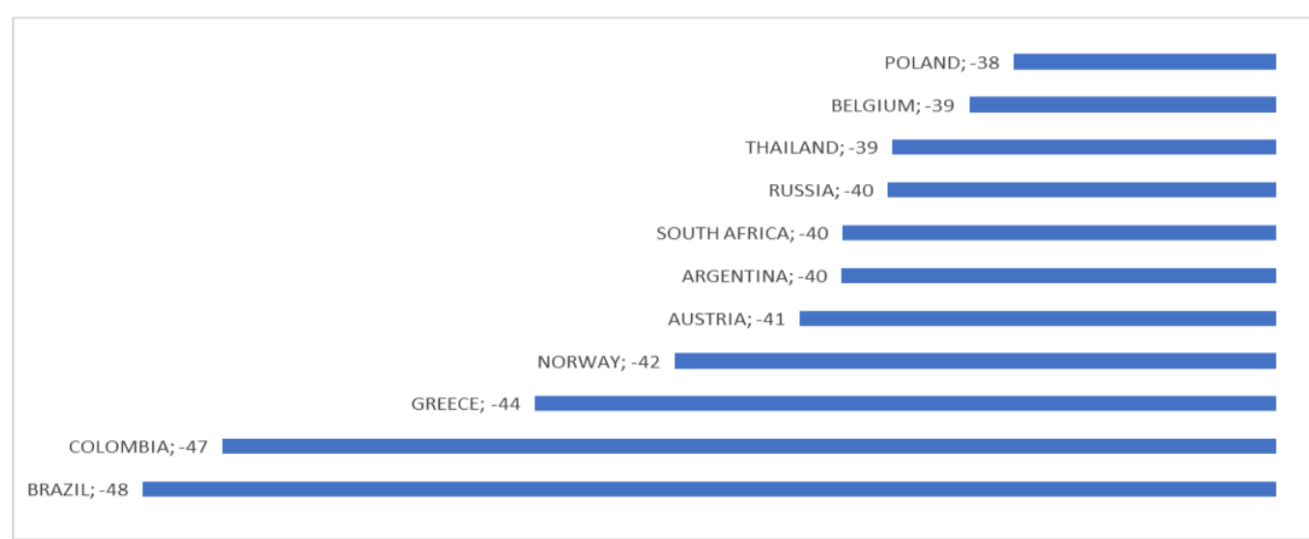

Figure 5. The 11 Worst Global Capital Market Performances in 2020

Source: Fernandes (2020)

The figure shows the worst performing capital market index in 2020 which is starts with the Polish capital market that experienced a decline of $38 \%$. The worst performing capital market occurred in the Brazilian capital market which decreased by $48 \%$. Moreover, the decline in the world capital market sector in 2020 is as follows: 


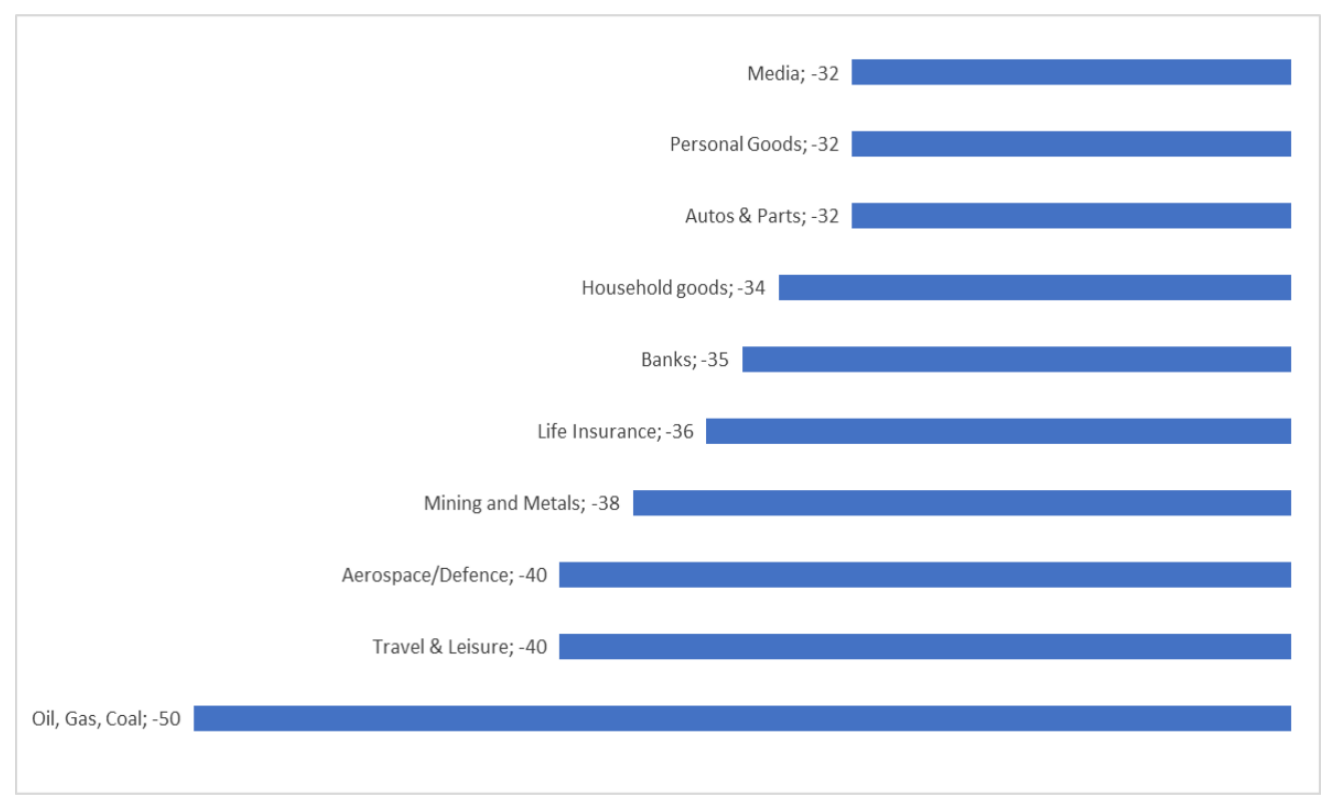

Figure 6. Decline in World Capital Market Sectoral Prices in 2020 Source: Fernandes (2020)

The graph shows the decline in stock prices and the decline in profits in the sector, oil, gas, coal. The decline was minus $50 \%$ while almost all sectors experienced a $32 \%$ decline. The volatility of the world stock market implies how uncertain the investment climate is during the COVID-19 pandemic, which is followed by uncertainty about the future of the COVID-19 pandemic.

In regards, this study examines to analyse the effect of the economic crisis due to the COVID-19 pandemic on the potential financial distress of companies that are members of the Islamic capital market category. This research also addresses to prove whether sharia companies have the same impact from the COVID-19 pandemic, by comparing data with different years (2019 and 2020). Thus, it is expected that it can be seen whether there will be companies experiencing financial distress. Are there any companies that experience the potential for financial distress, or in contrary, are there any sharia companies that experience improved financial performance? In addition, this research aims to find out how much influence does the company's condition in the previous period, profitability, liabilities, and liquidity give affect the potential to financial distress.

\section{LITERATURE REVIEW}

The Islamic capital market is a capital market that its operations are based on Islamic principles which do not allow elements of usury (riba), gambling (maysir), and speculation (gharar). In the Islamic capital market, all traded instruments must comply to the principles of Islamic Sharia. The Sharia Advisory Council (SAC) is tasked with finding out if the criteria in the survey form are met, questions are made, as well as the company's annual financial reports to determine which companies are in accordance with the principles of the shariah category. As for the criteria there are at 
least three basic categories, which are business activities, sources of income, and financial position. Moreover, Jaballah et al. (2018) explained that criteria involving financial aspects, that is limited company debt are considered a positive response by investors, and a low level of corporate debt indicates a lower risk of bankruptcy.

In terms of financial analysis, bankruptcy itself is a condition in which the company is no longer able to pay off its obligations. According to Brigham and Ehrhardt (2011), bankruptcy is a failure if the company experiences economic distressed, which means that the level of return is less than the cost of capital. There are two forms of economic distressed. One, technical default occurs when the company fails to meet one or more of the abilities to pay debts. Two, technical insolvency occurs when the company is unable to pay debts at a predetermined time. Based on the definition or criteria of bankruptcy according to Copeland and Weston (1988); Brigham and Ehrhardt (2011), as it is very relevant to support Zmijewski's (1984) bankruptcy analysis model. In result, the Zmijewski model is expected to be used to analyze the potential for financial distress of shariah companies caused by the COVID-19 pandemic.

There are several relevant studies that discuss the impact of the economic crisis on the capital market, which is in accordance with the research plan of this article. First, Chowdhury et al. (2021) examined the impact of the COVID-19 pandemic. They compared the Islamic stock market index with conventional market indexes, with the object of research being the Dow Jones global index and stock market indexes from developing countries. The research focuses on ten main sector categories including raw materials, consumer goods, consumer services, finance, health care, industry, oil and gas, technology, telecommunications, and utilities. This study uses an analysis of reaction, risk, and recovery due to COVID-19. The results showed that the Islamic stock index experienced a lower decline and a faster recovery compared to the partner index (conventional) during the COVID-19 pandemic (Chowdhury et al., 2021).

Second, Sahoo (2021)analyzed empirically that is daily Indian stock market closing data by dividing into two sub-periods a week before and during the COVID-19 pandemic. The result was a negative impact due to the COVID-19 pandemic. Third, Didier et al. (2021) concluded that the COVID-19 pandemic has affected economic activity around the world. It had hurt companies and driven many of them to bankruptcy. The economic crisis triggered by a pandemic is very different with past crises. It is important to maintain company relationships with key stakeholders (such as workers, suppliers, customers, and creditors) to avoid inefficient bankruptcy and long-term adverse economic effects. Companies get benefit from "hibernation", with cost efficiencies during the COVID-19 pandemic, keeping credit where necessary to stay alive until the crisis subsides. The existing legal and regulatory infrastructure is inadequate to deal with exogenous systemic shocks such as a pandemic. 
Fourth, Greenwood et al. (2020) concluded a wave of financial difficulties experienced by several companies with the result that some companies are able to survive and several others have the potential to face bankruptcy so that they will face potential liquidation or reorganization downsizing up to acquisitions. Overall, there are two main problems, namely legal problems, court congestion and overliquidation, and small firm failures.

Fifth, Habir and Wardana (2020) had identified that net external fund flows were negative or capital outflows occurred throughout 2020, with local investors taking some credit slack (restructuring). There was an increase in the composition of local investors in the bond and equity markets which is a welcome stabilizing trend. However, a prolonged slowdown will hurt more vulnerable businesses, particularly those with high debt levels. Non-performing loans (NPLs) have increased from $2.5 \%$ in January 2020 to $3.1 \%$ in the middle of the year, a prolonged pandemic will have a negative impact on economic recovery and further erode the level of capital in the banking sector the following year.

Sixth, in its policy summary, the OECD (2020) had investigated the possibility of corporate bankruptcy and the potential implications of corporate debt swells related to the COVID-19 outbreak by regression analysis and looking at the historical relationship between leverage and firm investment. It examined the potential impact of higher debt levels and higher on investment during the recovery. Against this backdrop, the policy summary had outlined a number of policy options for flattening the crisis-related bankruptcy curve, which could potentially affect companies' viability to reduce the risk of debt bloating and slow down the speed of recovery in the event of potential financial distress experienced companies.

Seventh, Tsoy and Heshmati (2017) had researched the impact of the 1997 and 2008 global financial crises in Asia on the capital structure of companies listed in the Korean Capital Market. This study found that the different effects of the two crises in 1997 and 2008, in terms of their influence on the capital structure and the speed of its adjustment before and after the crisis.

Eighth, Bărbuță-Mișu and Madaleno (2020) analyzed discriminant with five models to assess bankruptcy risk: Altman, Conan and Holder, Tafler, Springate, and Zmijewski in European countries for the period 2006-2015 by using the GMM method. At the end, it had the output that was the research Component analysis used to assess bankruptcy risk based on the discriminant analysis index is effective in determining the effect of company performance on bankruptcy risk.

Ninth, Lemos (2017) examined the impact of the crisis on the short and long term debt structure of 33 companies listed in Portugal, with the results obtained supporting the trade-off theory and pecking orders. The short-term debt ratio reported an increasing trend during the financial crisis while long-term debt recorded a decrease. 
Tenth, Saji (2018) examined the usefulness of the Z-Score model in measuring financial distress and predicting stock market failures. It is based solely on a single accounting model from Altman (1968), showing that stock market failures with distress Z-Scores provide strong evidence that corporate finance contributes significantly to the cross-sectional distribution of returns on equity.

Eleventh, Fosberg (2012) explained the impact of the financial crisis on the capital structure of companies in the US capital market. The results show that between 2006 and 2008 the financial crisis and recession simultaneously caused to increase the market debt ratio of company (average 5.5\%), after recovering from the impact of the recession. The capital structure of almost all companies was found that is $5.1 \%$ of the accumulated debt that occurred was the impact of the financial crisis. In addition, it was found that the effect of the financial crisis on the company's capital structure was almost entirely back at the end of 2010.

Twelfth, Prusak (2018) addressed that the progress rate of bankruptcy prediction research in former Eastern European countries compared to the latest global research trends. At the end, the bankruptcy prediction studied that the most advanced results are the Czech Republic, Poland, Slovakia, Estonia, Russia and Hungary. Belarusians Bulgaria and Latvia are the opposite.

Thirteenth, Samour and Hassan (2016) examined the impact of the financial crisis on the capital structure of different industry groupings such as consumer goods industry, consumer services, healthcare, industry, and technology before and during the 2008 financial crisis. It found that the capital structure changed differently between industries and there is a significant impact of the crisis on the consumer care and health industry.

Fourteenth, Khudyakova and Shmidt (2019) analyzed macro and microeconomic parameters carefully, as well as identify consistent patterns and make relevant predictions aimed at preventive management in creating a sustainable economy. A sustainable economy that is facing the fluctuations which is caused by cycle over time the company. It must develop, introduce, and improve the stability of the control system with. The control is in the form of an integrated system with several systems in marketing, production, and financial control.

Fifteenth, Njiforti (2015) studied the impact of the crisis on the capital market in Nigeria using the vector error correction (VEC) model. Moreover, global impact is a significant decline in the Nigerian capital market in the short and long term.

Sixteenth, Ashraf et al. (2019) were comparing the accuracy of traditional distress prediction models for companies that are in the early and advanced stages of developing difficulties in the Pakistan market during 2001-2015. This study was conducted by comparing companies that worked under the pressure of the financial crisis and during normal conditions. The study concluded that the predictive capabilities of all traditional financial distress prediction models decreased during periods of financial crisis. 
The previous research mentioned above is considered relevant in making new research concepts related to the current conditions of the COVID-19 pandemic which caused an economic crisis and has a potential impact on financial distress on Islamic companies in Indonesia. However, this research puts forward the suspicion whether all Islamic companies in Indonesia have the potential to experience financial distress or even have a positive impact due to the COVID-19 pandemic.

There are hypothesis in this study among others:

$H_{1}$ : there was a decline in the financial performance of companies that are members of Jll during the Covid-19 outbreak;

$\mathrm{H}_{2}$ : there are several companies that are members of JII able to survive and experience positive performance in the presence of COVID-19;

$H_{3}$ : the profitability ratio, $R O E$, has a significant positive effect on the financial performance of companies that are members of JII;

$\mathrm{H}_{4}$ : the liability ratio, DER, has a significant negative effect on the financial performance of companies that are members of JII; and

$H_{5}$ : the liquidity ratio, $\mathrm{CR}$, has a significant positive effect on the financial performance of companies that are members of $\mathrm{JII}$.

\section{RESEARCH METHOD}

This research is quantitative research which is using secondary samples obtained from the website of the Indonesia Stock Exchange (IDX), that is quarterly time series data is started from the first quarter of 2019 to the third quarter of 2020. Also, the object of research is Islamic stocks using the company's financial statements which are included in the category JII. The first step in carrying out the data analysis process is to enter the variables $X_{1}$ (profitability ratio or ROE), $X_{2}$ (liability ratio or DER), $X_{3}$ (liquidity ratio or $(R)$, into the Zmijewski model to find the Z-Score.

Profitability ratios (ROE) are used for measuring the company in generating profits at the level of sales, assets, and certain stock equity. Kasmir (2014) explained that the profitability ratio provides a level of management effectiveness of a company, because it generates profits from sales and investment income. The calculation of the profitability ratio can be done by using a comparison between the various components in the financial statements in a certain period. While liability ratio (DER) is used for measuring the ratio between total debt and equity. Liability ratio can be defined as the amount of capital financed by debt. Last, liquidity (CR) is used in assessing the company's ability in short-term conditions.

These following are explanations of the three ratios (ROE, DER, CR) using a mathematical model:

Table 1.

Operational Definition of ROE, DER, CR

\begin{tabular}{ccc}
\hline Descripton & Abbreviation & Calculation \\
\hline Return on Equity & ROE & Net Profit/Equity
\end{tabular}


Debt to Equity Ratio Liquidity
DER

CR
Total Liability/Equity

Current Asset/Current Liability

Source: Robinson et al. (2008)

Furthermore, an initial analysis will be carried out to see the potential financial distress on the performance of each company. It means by comparing the period before the COVID-19 pandemic with the time of the COVID-19 pandemic. Zmijewski's assessment model or method is a prediction model produced by Zmijewski in 1983. The accuracy of this model in estimating data is $99 \%$ (Avenhuis, 2013).

Quantitative research is research by calculating financial feasibility using the Zmijewski model Z-Score:

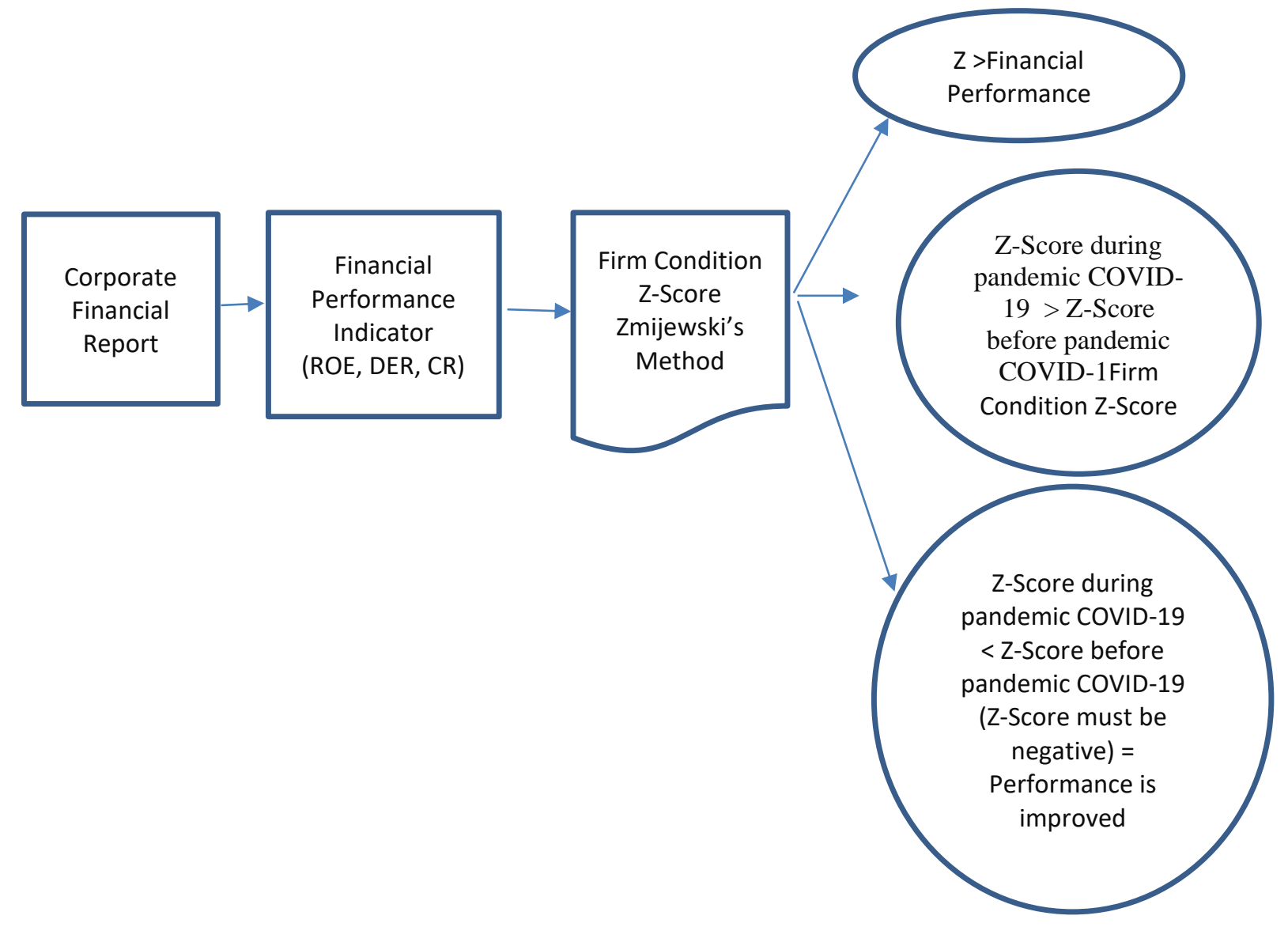

Figure 7. Conceptual Diagram

The next step is to estimate the model and analysis of all variables, both dependent variable and the independent variable, using the Panel Generalized Method of Moments (GMM) Panel Data estimation developed by Arellano and Bond (1991). This GMM estimation method produces unbiased, consistent, and efficient parameter estimates. It adequately addresses both of individual and time-specific effects. The Arellano and Bond method were developed by Blundell and Bond called the GMM-System Estimator, to produce a more efficient parameter estimation. These models and estimation methods are used to explore the potential for financial 
distressed analysis of the performance of Islamic companies in the 2019 period before the COVID-19 pandemic and the 2020 period during the COVID-19 pandemic.

In order to estimate, dynamic panel regression GMM will be used in this research. The method is done because the number of $N>T$ ( $N=$ number of observations and $\mathrm{T}=$ number of time periods) that is using instrument variables, instrument $Z$ must be exogenous, number of instruments $Z \leq N$. It uses to see whether the data is valid or not that is used as a research variable (Arellano \& Bond, 1991).

The next stage is to test the effect of each independent variable (profitability, liability, and liquidity) on the dependent variable (the score/value of the Z-Score bankruptcy test). This test is implementing of the model and estimation and analysis that was used of the data panel generalized method of moments (GMM) by Arellano and Bond (1991). This GMM estimation method produces parameter estimates that are unbiased, consistent, and efficient.

The Arellano and Bond method developed by Blundell and Bond that is called the GMM-System Estimator. Moreover, it is by combining the condition moments and the instrument matrix between the first difference model and the current level model to produce a more efficient parameter estimate. In the GMM method panel data method, the Arellano-Bond serial correlation test autocorrelation must be tested by looking at the significance values of AR1 and AR2. They are part of the autocorrelation test indicator, which is used as a decision making from the estimation test. If the value of AR1 and AR2 is one of them $\alpha>5 \%(0.05)$, the consistency of the GMM results is described by a statistically insignificant value. It aims to determine the consistency that is indicated by statistical values so that there is no autocorrelation of error components in the first different (Arellano \& Bond, 1991). Panel data modelling in estimating this research is as follows:

$Z_{i t}=\beta_{0}+\beta_{1} Z_{i t-1}+\beta_{2} \ln N e w X_{1 i t}+\beta_{3} \ln X_{2 i t}+\beta_{4} \ln X_{3 i \mathrm{t}}+e_{i}$

Note: $Z$ = Score Zmijewski assessment method; $X_{1}=$ Profitability Ratio (ROE); $X_{2}=$ Liability Ratio (DER); $X_{3}=$ Liquidity Ratio (CR)

wherein $i$ is $1,2,3, \ldots, \mathrm{n}$ and $\mathrm{t}$ is $1,2,3, \ldots, t$, which means the observation of the unit cross section at $\mathrm{i}$ and time period $\mathrm{t}$. In addition, there is $e$ is the regression error in the panel data estimation. In the model, $L$ (natural logarithm) is written that the natural logarithm itself is used to produce regression coefficients in the form of elastic, usually used to estimate data in the form of ratios, such as the data used in this study. In this estimation model, one of the independent variables, namely the profitability ratio, is because the condition of company's profit is sometimes minus, that the specific variable is transformed first. In result, it becomes NewX $X_{1}$, so that the natural logarithmic process can be carried out.

Furthermore, in looking at the validity of the instrumental variables, the results can be seen from the probability value of J-Statistics and the amount of the rank instrument from the estimated number of variables. Hence, if the low J-Statistic 
Probability value is interpreted as evidence that contradicts the validity set by the instrument. Thus, it must be seen from the rank instrument which is smaller than the estimated number of variables interpreted as evidence contrary to the validity of the instrument set. In addition, the consistency of the GMM-System Estimator requires the absence of second-order residual autocorrelation. To verify whether there is a serial correlation in terms of the idiosyncratic error of the equation in difference, Arellano and the AR1 and AR2 Bond tests were performed. The existence of secondorder serial correlation is a sign of specification error, and the estimation results are not suitable for analysis.

\section{RESULT AND ANALYSIS}

The COVID-19 pandemic has resulted in an economic crisis. That is giving the impact on the economic sector, that is it turns out that COVID-19 also has an influence on company performance, which has the potential for financial distress to Islamic companies that listed in JII. It focuses on Islamic companies as an object of research in the period before and when the COVID-19 pandemic occurred. Thus, it can be analysed that the COVID-19 pandemic in general has a negative impact on the financial performance of sharia companies. However, there are several companies that have financial performance is better during the COVID-19 pandemic. Previous research that has similarities to this research is the concept of a research idea conducted by Sahoo (2021) which investigated or empirically analysed the Indian stock market daily by dividing into two sub-periods a week before and during the COVID-19 pandemic, with the results of this study negative impact due to the COVID19 pandemic. As for what distinguishes this research is the object of research, research location, research methodology, research period, and the concept of potential bankruptcy that underlies this research. This research provides new knowledge that the COVID-19 pandemic has an impact on the entire economic sector.

Research on the potential for financial distress that focuses on using the momentum before and during the COVID-19 pandemic can be briefly analysed using the Z-Score Zmijewski model, with an overview of the results as follows: 
Table 2.

Z-Score Potential Financial Distress

\begin{tabular}{|c|c|c|c|c|c|c|c|c|c|c|c|c|}
\hline \multirow{3}{*}{$\begin{array}{l}\text { Firm } \\
\text { Code }\end{array}$} & \multicolumn{10}{|c|}{ Z - Score } & \multirow{3}{*}{$\begin{array}{c}\text { Compare } \\
\text { Financial } \\
\text { Performance } \\
2020 \text { (Q1, Q2, } \\
\text { Q3) vs 2019 } \\
\text { (Q1, Q2, Q3) }\end{array}$} & \multirow{3}{*}{$\begin{array}{l}\text { Compare } \\
\text { Financial } \\
\text { Performance } \\
\text { before COVID- } \\
19 \text { vs During } \\
\text { COVID-19 }\end{array}$} \\
\hline & \multicolumn{4}{|c|}{ Before Pandemic COVID-19 } & \multirow{2}{*}{$\begin{array}{c}\text { Avarage Z- } \\
\text { Score Q1, } \\
\text { Q2, Q3 } \\
2019\end{array}$} & \multirow{2}{*}{$\begin{array}{l}\text { Avarage Z- } \\
\text { Score } \\
\text { before } \\
\text { Pandemic } \\
\text { COVID-19 }\end{array}$} & \multicolumn{3}{|c|}{ During Pandemic COVID-19 } & \multirow{2}{*}{$\begin{array}{l}\text { Avarage Z- } \\
\text { Score } \\
\text { During } \\
\text { Pandemic } \\
\text { COVID-19 } \\
\end{array}$} & & \\
\hline & 2019:Q1 & 2019:Q2 & 2019:Q3 & 2019:Q4 & & & 2020:Q1 & 2020:Q2 & 2020:Q3 & & & \\
\hline ADRO & -4.8317 & -4.9680 & -4.8946 & -4.7291 & -4.8981 & -4.8559 & -4.7270 & -4.6373 & -4.4402 & -4.6015 & 0.2966 & 0.2544 \\
\hline AKRA & -4.6661 & -4.6626 & -4.6457 & -4.6300 & -4.6581 & -4.6511 & -4.7075 & -4.7021 & -4.7168 & -4.7088 & -0.0507 & -0.0577 \\
\hline ANTM & -4.4132 & -4.4267 & -4.4369 & -4.3097 & -4.4256 & -4.3966 & -3.9767 & -4.3025 & -4.5314 & -4.2702 & 0.1554 & 0.1264 \\
\hline ASII & -4.8931 & -4.8643 & -4.8977 & -4.8989 & -4.8850 & -4.8885 & -4.7954 & -4.9136 & -4.7933 & -4.8341 & 0.0510 & 0.0544 \\
\hline BRPT & -4.1906 & -4.1781 & -4.1351 & -4.2431 & -4.1679 & -4.1867 & -4.0520 & -4.0494 & -4.1660 & -4.0891 & 0.0788 & 0.0976 \\
\hline BSDE & -4.6685 & -4.9245 & -4.7462 & -4.6923 & -4.7797 & -4.7579 & -4.4097 & -4.2218 & -4.3433 & -4.3249 & 0.4548 & 0.4330 \\
\hline BTPS & -5.4024 & -5.3792 & -5.3755 & -5.3620 & -5.3857 & -5.3798 & -5.4487 & -4.8704 & -4.7467 & -5.0219 & 0.3638 & 0.3579 \\
\hline CPIN & -5.0018 & -5.0825 & -5.0468 & -5.0513 & -5.0437 & -5.0456 & -5.0333 & -4.9321 & -4.8983 & -4.9545 & 0.0892 & 0.0911 \\
\hline CTRA & -4.5782 & -4.4100 & -4.3925 & -4.5692 & -4.4602 & -4.4875 & -4.4363 & -4.3229 & -4.3091 & -4.3561 & 0.1041 & 0.1314 \\
\hline ERAA & -4.3889 & -4.4318 & -4.4489 & -4.5176 & -4.4232 & -4.4468 & -4.6166 & -4.4619 & -4.5953 & -4.5579 & -0.1348 & -0.1112 \\
\hline EXCL & -4.2343 & -4.3167 & -4.3321 & -4.3354 & -4.2944 & -4.3046 & -5.4805 & -4.9278 & -4.7674 & -5.0586 & -0.7642 & -0.7539 \\
\hline ICBP & -5.3156 & -5.2829 & -5.2436 & -5.1671 & -5.2807 & -5.2523 & -5.5811 & -5.3300 & -5.0681 & -5.3264 & -0.0457 & -0.0741 \\
\hline INCO & -4.1009 & -4.1676 & -4.2945 & -4.4295 & -4.1877 & -4.2481 & -4.5600 & -4.5343 & -4.5240 & -4.5395 & -0.3518 & -0.2913 \\
\hline INDF & -4.9144 & -4.8811 & -4.8166 & -4.8281 & -4.8707 & -4.8601 & -4.8719 & -4.8669 & -4.7417 & -4.8268 & 0.0439 & 0.0333 \\
\hline INDY & -4.3610 & -4.2704 & -4.0763 & -4.1196 & -4.2359 & -4.2068 & -3.6599 & -3.8709 & -3.6992 & -3.7433 & 0.4926 & 0.4635 \\
\hline INTP & -4.5903 & -4.5525 & -4.6037 & -4.6487 & -4.5822 & -4.5988 & -4.5948 & -4.4740 & -4.5902 & -4.5530 & 0.0291 & 0.0458 \\
\hline ITMG & -5.0972 & -4.9766 & -4.9616 & -4.9298 & -5.0118 & -4.9913 & -4.5968 & -4.5864 & -4.5518 & -4.5783 & 0.4334 & 0.4130 \\
\hline JPFA & -4.7519 & -4.9572 & -4.8185 & -4.9412 & -4.8425 & -4.8672 & -4.7861 & -4.3455 & -4.3643 & -4.4986 & 0.3439 & 0.3686 \\
\hline
\end{tabular}


Avianto Nugroho, Wasiaturrahma, Putri Anggia

\begin{tabular}{|c|c|c|c|c|c|c|c|c|c|c|c|c|}
\hline JSMR & -4.6921 & -4.6177 & -4.5715 & -4.5973 & -4.6271 & -4.6197 & -4.6222 & -4.1110 & -4.1101 & -4.2811 & 0.3460 & 0.3385 \\
\hline KLBF & -5.0022 & -5.0610 & -5.0403 & -4.9998 & -5.0345 & -5.0258 & -5.0165 & -5.0471 & -4.9986 & -5.0207 & 0.0137 & 0.0051 \\
\hline LPPF & -5.6260 & -10.3093 & -8.4250 & -7.7209 & -8.1201 & -8.0203 & -2.6710 & -0.8221 & 0.8453 & -0.8826 & 7.2375 & 7.1377 \\
\hline PTBA & -5.4608 & -5.4036 & -5.3846 & -5.2991 & -5.4164 & -5.3870 & -5.1008 & -4.9946 & -4.9016 & -4.9990 & 0.4174 & 0.3881 \\
\hline PTPP & -4.3835 & -4.3899 & -4.3811 & -4.4531 & -4.3848 & -4.4019 & -4.0946 & -4.1022 & -4.1083 & -4.1017 & 0.2831 & 0.3002 \\
\hline SCMA & -5.7582 & -5.6893 & -5.4566 & -5.2640 & -5.6347 & -5.5420 & -5.2562 & -5.3598 & -5.3855 & -5.3338 & 0.3009 & 0.2082 \\
\hline SMGR & -4.3733 & -4.3585 & -4.4621 & -4.5761 & -4.3980 & -4.4425 & -4.4633 & -4.3943 & -4.5005 & -4.4527 & -0.0547 & -0.0102 \\
\hline TLKM & -5.3152 & -5.2984 & -5.2330 & -5.0845 & -5.2822 & -5.2328 & -5.2273 & -5.2512 & -5.2228 & -5.2338 & 0.0485 & -0.0010 \\
\hline UNTR & -5.2196 & -5.1588 & -5.1644 & -5.1218 & -5.1809 & -5.1661 & -4.7765 & -4.8825 & -4.7867 & -4.8152 & 0.3657 & 0.3509 \\
\hline UNVR & -7.6942 & -10.6855 & -8.9875 & -10.4245 & -9.1224 & -9.4480 & -8.8300 & -7.9188 & -9.1999 & -8.6496 & 0.4728 & 0.7984 \\
\hline WIKA & -4.4882 & -4.6515 & -4.6535 & -4.7729 & -4.5977 & -4.6415 & -4.2493 & -4.2814 & -4.1344 & -4.2217 & 0.3760 & 0.4198 \\
\hline WSBP & -4.9385 & -4.6832 & -4.6346 & -4.6841 & -4.7521 & -4.7351 & -4.4927 & -4.2384 & -3.0266 & -3.9192 & 0.8328 & 0.8159 \\
\hline
\end{tabular}

Source: Data Processed (2021) 
The table shows that it should be explained beforehand if the Z-Score is getting negative. In sum, it can be said that the company will be healthier.

Based on the table information, by comparing the Z-Score before and during the COVID-19 pandemic, according to the Z-Score calculation criteria, it turns out that in general, Islamic companies that are members of $\mathrm{Jll}$ have the following financial performances:

1. There is one company out of thirty companies that are members of $\mathrm{JII}$, that is one company with the code LPPF experienced financial distress in the third quarter of 2020 with a Z-Score> 0. It has a reason that due to the company is working on the public sector (retail), which is directly affected by the large-scale social restriction (PSBB), wherein the policy is imposed by the government. Moreover, it aims to anticipating an increase of COVID-19 sufferers. Thus, it results effects in a reduced number of visitors or buyers. These results prove the basic theory of market balance (supply and demand) and are in accordance with research that has been carried out by Sahoo (2021) with the object of research on the Indian stock market daily by dividing two sub-periods a week before and during the COVID-19 pandemic, with the results there was a negative impact on the capital market due to the COVID-19 pandemic (Sahoo, 2021).

2. There are twenty-two companies that experienced a decline in financial performance (financial distress occurred). It can be seen from the comparison of the average Z-Score at the time of the COVID-19 pandemic which was greater than the average Z-Score before the COVID-19 pandemic (difference in the average Z-Score is positive). These are both of comparing quarterly averages and total means. This is in accordance with research conducted by Sahoo (2021) with the result that there was a negative impact on the capital market due to the COVID-19 pandemic.

3. There were seven companies that experienced better performance during the COVID-19 pandemic. It can be seen from the average Z-Score during the COVID-19 pandemic which was smaller than the average Z-Score before the COVID-19 pandemic (difference in mean of Z-Score is negative). The seven companies that performed better at the time of the COVID-19 pandemic were three companies that worked related to information technology (ERAA, EXCL, TLKM). One company engaged in meeting household food needs (ICBP). There were two companies engaged in the mining and mineral processing sector (INCO, SMGR), and one company engaged in the trade and investment sector (AKRA). These companies are mainly on sectoral products are needed by the community to support daily activities. Hence, their performance in the financial period was good and the public's need for information technology increased. This is in accordance with research conducted by Greenwood et al. (2020), one of the results of which was that several companies were able to survive during the Covid-19 pandemic. It also proves the truth of 
several basic economic theories, namely Engel's curve theory, Giffen's goods theory, marginal substitution theory, and opportunity theory.

Furthermore, in looking at the influence of the relationship between the independent variables on the dependent variable and its consistency. Thus, it can be analysed using the GMM-System Estimator method with the following output:

Table 3.

Generalized Method of Moment/Dynamic Panel Data Estimated

\begin{tabular}{crrrr}
\hline \hline Variable & Coefficient & Std. Error & t-Statistic & Prob. \\
\hline \hline NEWZ(-1) & -0.163992 & 0.001230 & -133.3662 & 0.0000 \\
LOG_NEWX1_ & -10.20211 & 0.030876 & -330.4176 & 0.0000 \\
LOG_X2_- & -1.487391 & 0.517804 & -2.872498 & 0.0047 \\
LOG_X3_- & -1.133679 & 0.810662 & -1.398460 & 0.1642 \\
@LEV(@ISPERIOD("3")) & -0.012957 & 0.004677 & -2.770086 & 0.0064 \\
@LEV(@ISPERIOD("4")) & 0.014131 & 0.003754 & 3.764674 & 0.0002 \\
@LEV(@ISPERIOD("5")) & 0.011674 & 0.004024 & 2.901292 & 0.0043 \\
@LEV(@ISPERIOD("6")) & 0.014158 & 0.005636 & 2.512019 & 0.0131 \\
@LEV(@ISPERIOD("7")) & -0.011385 & 0.008607 & -1.322654 & 0.1881 \\
\hline \hline
\end{tabular}

Effects Specification

Cross-section fixed (first differences)

Period fixed (dummy variables)

\begin{tabular}{lllr}
\hline \hline Mean dependent var & 0.131086 & S.D. dependent var & 0.577642 \\
S.E. of regression & 0.121889 & Sum squared resid & 2.094815 \\
J-statistic & 18.87985 & Instrument rank & 23 \\
Prob(J-statistic) & 0.169591 & & \\
\hline
\end{tabular}

Source: Data Processed

The table depicts that the evaluation of dynamic panel data regression has some results with the GMM approach that has met the criteria for the best model. It can be seen from the J-Statistic Probability value is 0.169591 which can be categorized as insignificant at all levels of significance. Additionally, another thing that can be seen from the value of the instrument rank output which is 23 greater than the number of variables estimated by the number of nine variables. This shows that the instrument in the estimation model is valid and unbiased. Hereafter, it is to look at the autocorrelation of the model using the consistency test of estimation using ArellanoBond. The test, Table 4, shows that the probability value of AR 1 and AR2 is insignificant are at all levels of significance. In result, the estimation model does not have autocorrelation problems. 
Table 4.

Arellano-Bond Serial Correlation Test

\begin{tabular}{ccccc}
\hline \hline Test order & m-Statistic & rho & $\underline{\underline{\text { SE}}(\text { rho })}$ & Prob. \\
\hline \hline$\underline{\operatorname{AR}(1)}$ & -0.892560 & -0.061707 & 0.069135 & 0.3721 \\
$\underline{\operatorname{AR}(2)}$ & -1.287370 & -0.506443 & 0.393394 & 0.1980 \\
\hline \hline
\end{tabular}

Source: Data Processed

The discussion focuses on the independent variables that affect the determination of the Z-Score (financial distress). The significance level of $5 \%$ test, on each independent variable. Thus, the profitability ratio $\left(X_{1}\right)$ is the most influential variable in determining the Z-Score (financial distress, with the explanation that if the profitability ratio increases by $1 \%$, the Z-Score will be down about $10.2 \%$ ).

Furthermore, Z-Score is more negative that indicates of the company is getting better. In the partial analysis between these variables, the liquidity ratio $\left(X_{3}\right)$ does not have a significant effect on determining the Z-Score (financial distress). Liability variable $\left(X_{2}\right)$ has a significant effect on the Z-Score at the $5 \%$ significance level. The $Z$ variable in the previous period ( $Z$ lag) also affects the $Z$ variable in that period, and at a significant level of $5 \%$. It can be concluded that from all the independent variables estimated in the model, there are three variables that influence the determination of financial distress, and the one that most dominantly affects the company's financial health is the company's profitability ratio. Specifically, the company's liquidity ratio during the COVID-19 pandemic itself does not really affect the company's financial distress, it has possibility that is because of the time span was still very short.

\section{CONCLUSION}

The results of this study in general are that COVID-19 has an impact on the decline in the financial performance of Islamic companies. Twenty-two Islamic companies experienced a decline in financial performance, from before the COVID-19 pandemic to the time of the COVID-19 pandemic. Seven companies experienced an increase in financial performance during the COVID-19 pandemic and a company experiencing direct financial distress. This research is expected to give an open insight into the impact of the COVID-19 crisis by comparing financial performance before and during the COVID-19 pandemic in each company sector, so that new knowledge will emerge relating to risks and potentials return on investment activity as well as proving some basic economic theories. However, this research does not examine macroeconomics and macroeconomic variables in knowing the overall impact of causality between macroeconomic conditions and capital market conditions, especially the shariah capital market. Further research can be developed to reveal how long the company's financial performance will return to normal, as well as what external factors 
play a role in overcoming the crisis in the capital market, especially Islamic companies. Thus, it is hoped that the government's role in overcoming the crisis due to the COVID19 pandemic will be right on target.

\section{ACKNOWLEDGMENT}

After leaving bachelor's degree school for more than 14 years, I have begun to explore my ability to write scientific articles again, relating to the economic crisis caused by the COVID-19 pandemic. I prove this paper to my wife who is running her post-doctoral program in Europe, even though I have a career in the professional world, there is still the ability to write. Hopefully, this article is, acceptable. Thus, it will motivate me to write the next articles, as well as motivate my wife to seek blessings by studying all the time. Last but not least, it will motivate Muhammad Qawiy Avianto that is my beloved son, becoming a knowledgeable person, and full of blessings.

\section{REFERENCES}

Arellano, M., \& Bond, S. (1991). Some Tests of Specification for Panel Data: Monte Carlo Evidence and an Aplication to Employment Equations. The Review of Economic Studies, 58(2), 277-297. https://doi.org/10.2307/2297968

Arnani, M. (2020). Timeline Wabah Virus Corona, Terdeteksi pada Desember 2019 hingga Jadi Pandemi Global. Kompas.Com. https://www.kompas.com/tren/read/2020/03/12/113008565/timeline-wabahvirus-corona-terdeteksi-pada-desember-2019-hingga-jadi?page=all

Ashraf, S., Félix, E. G. S., \& Serrasqueiro, Z. (2019). Do Traditional Financial Distress Prediction Models Predict the Early Warning Signs of Financial Distress? Journal Risk Financial Management, 12(2), 55. https://doi.org/10.3390/jrfm12020055

Avenhuis, J. O. (2013). Testing The Generalizability of The Bankruptcy Prediction Models of Altman, Ohlson, and Zmijewski for Dutch Listed and Large Non-Listed Firms [University of Twente]. http://essay.utwente.nl/64326/

Bărbuță-Mișu, N., \& Madaleno, M. (2020). Assesment of Bankruptcy Risk of Large Companies: European Countries Evolution Analysis. Journal of Risk and Financial Management, 13(3), 58. https://doi.org/10.3390/jrfm13030058

Brigham, E. F., \& Ehrhardt, M. C. (2011). Financial Management: Theory and Practice (O. H. Mason (ed.); 13th ed.). South-Western Cengage Learning.

Chowdhury, M. I. H., Balli, F., \& de Bruin, A. (2021). Islamic Equity Markets Versus Their Conventional Counterparts in the COVID-19 Age: Reaction, Resilience, and Recovery. International Review of Finance, 1-10. https://doi.org/10.1111/irfi.12349

Copeland, T. E., \& Weston, J. F. (1988). Financial Theory and Corporate Policy (3rd ed.). Addison-Wesley Publishing Co.

Didier, T., Huneeus, F., Larrain, M., \& Schmukler, S. L. (2021). Financing Firms in Hibernation during The COVID-19 Pandemic. Journal of Financial Stability, 53. https://doi.org/10.1016/j.jfs.2020.100837

Fernandes, N. (2020). Economic Effects of Coronavirus Outbreak (COVID-19) on the 
World Economy (WP-1240-E). https://doi.org/10.2139/ssrn.3557504

Fosberg, R. H. (2012). Capital Structure and Financial Crisis. Journal of Finance and Accountancy, 11(3), 1-10. https://www.aabri.com/jfa.html

Greenwood, R., Iverson, B., \& Thesmar, D. (2020). SIZING UP CORPORATE

RESTRUCTURING IN THE COVID CRISIS (No. 28104). https://doi.org/10.3386/w28104

Habir, M. T., \& Wardana, W. (2020). COVID-19's Impact on Indonesia's Economy and Financial Markets. http://hdl.handle.net/11540/12952

Jaballah, J., Peillex, J., \& Weill, L. (2018). Is Being Sharia compliant worth it? Economic Modelling, 72, 353-362. https://doi.org/10.1016/j.econmod.2018.02.011

Kasmir, K. (2014). Bank Dan Lembaga Keuangan Lainnya. Raja Grafindo Persada.

Khudyakova, T. A., \& Shmidt, A. V. (2019). Impact of The Global Recession on Financial and Economic Sustainability of Industrial Companies. European Research Studies Journal, 22(1). https://www.um.edu.mt/library/oar/handle/123456789/41234

Lemos, J. A. R. (2017). The Impact of Flnancial Crisis on Portugese Firms' Capital Structure [University Institute of Lisbon]. https://repositorio.iscteiul.pt/handle/10071/15763

Listyorini, L. (2020). Memahami tentang Pembatasan Sosial Berskala Besar (PSBB). Investor.Id. https://investor.id/investory/memahami-tentang-pembatasansosial-berskala-besar-psbb

Njiforti, O. (2015). Impact of The 2007-2008 Global Financial Crisis on th eStock Market in Nigeria. Journal of Applied Statistics, 6(1), 49-68. https://dc.cbn.gov.ng/jas/vol6/iss1/3/

OECD. (2020). Insolvency and Debt Overhang Following the COVID-19 Outbreak: Assessment of Risks and Policy Responses. Tackling Coronavirus Series. https://www.oecd.org/coronavirus/policy-responses/insolvency-and-debtoverhang-following-the-COVID-19-outbreak-assessment-of-risks-and-policyresponses-7806f078/\#annex-d1e2417

Prusak, B. (2018). Review of Research into Enterprise Bankruptcy Prediction in Selected Central and Eastern European Countries. International Journal of Flnancial Studies, 6(3), 1-28. https://doi.org/10.3390/ijfs6030060

Robinson, T. R., van Greuning, H., Henry, E., \& Broihahn, M. A. (2008). International Financial Statement Analysis. John Wiley \& Sons.

Sahoo, M. (2021). COVID-19 impact on stock market: Evidence from the Indian stock market. Journal of Public Affairs. https://doi.org/10.1002/pa.2621

Saji, T. G. (2018). Financial Distress and Stock Market Failures: Lessons from Indian Realty Sector. Vision: The Journal of Business Perspective, 22(1), 50-60. https://doi.org/10.1177/0972262917750244

Samour, S., \& Hassan, L. (2016). Capital Structure and Firm Performance: Did the Financial Crisis Matter?: A cross-industry study [Uppsala University]. http://uu.diva-portal.org/smash/record.jsf?pid=diva2\%3A944378\&dswid=3178

Tsoy, L., \& Heshmati, A. (2017). Impact of Financial Crises on Dynamics of Capital Structure: Evidence from Korean Listed Companies (IZA DP No. 10554). 
https://ideas.repec.org/p/iza/izadps/dp10554.html

UNCTAD. (2021). World Investment Report 2021.

World Economic Outlook. (2020). World Economic Outlook, April 2020: The Great Lockdown. https://www-imf-

org.translate.goog/en/Publications/WEO/Issues/2020/04/14/weo-april-

2020.?_x_tr_sl=en\&_x_tr_tl=id\&_x_tr_hl=id\&_x_tr_pto=nui,op 